\title{
Negativní parlamentarismus v Ústavní listině Československé republiky, inspirace a její limity
}

\author{
Ondřej Preuss
}

Právnická fakulta, Univerzita Karlova

Kontaktni e-mail:preuss@prf.cuni.cz

The Negative Parliamentarism of the Constitutional Charter of the Czechoslovak Republic, Inspiration and its Limits

\begin{abstract}
:
It has been 100 years since the adoption of the Constitutional Charter of the Czechoslovak Republic. The tradition of this document is alive in the constitutional order of the Czech Republic. However, this tradition cannot be absolutized, it would confuse the interpretation of the current legal system. While the Constitutional Charter of the Czechoslovak Republic from 1920 was built on the so-called principle of negative parliamentarism, today the constitutional order is built on the so-called positive parliamentarism, which does not allow "non-political" government. De lege ferenda, the question is whether it would not be more appropriate to strengthen the positive parliamentarism and return to 1918 - to elect a government.
\end{abstract}

Keywords: parliamentarism; constitutional tradition; Constitutional Charter of the Czechoslovak Republic 1920

Klíčová slova: parlamentarismus; ústavní tradice; Ústavní listina 1920

DOI: $10.14712 / 2464689 X .2021 .21$ 
Uplynulo více než sto let od přijetí Ústavní listiny Československé republiky (dále jen Ústavní listina 1920). ${ }^{1}$ Při zahájení schůze Národního shromáždění, které Ústavní listinu 1920 schválilo, jeho předseda František Tomášek mimo jiné pronesl: „Každý z nás necht’ je si plně vědom toho, že slova jeho budou poslouchána tisíci, statisíci, snad miliony našich současníků a že mluví také k těm, kdož přijdou po nás, k budoucím generacím.“2

Měl pravdu, ostatně důkazem je i tento text a mnohé odborné debaty a konference těmto „základům ústavy“ věnované. Tradice Ústavní listiny 1920 je jistě i nadále živá v ústavním pořádku České republiky, což by ctihodné zástupce, kteří se únorové schůze Národního shromáždění účastnili, jistě potěšilo. Je také fakt, že současná Ústava $3{ }^{3}$ byla touto Ústavní listinou 1920 velmi výrazně ovlivněna. ${ }^{4}$

Cílem tohoto článku je však prokázat, že tuto tradici nelze absolutizovat, to by interpretaci současného právního řádu zatemnilo a posunulo nesprávným směrem. To platí zejména v oblasti parlamentarismu a vztahu vlády a prezidenta republiky. V oblasti vztahu vlády a Poslanecké sněmovny nelze totiž o tradice první československé republiky a výklad Ústavní listiny 1920 opírat interpretaci současného ústavního systému. Je potřeba si uvědomit, že praxe první československé republiky nebyla ideální a harmonická. Hojně zaznívala kritika nepotismu a elitářství. ${ }^{5}$ Základní rozdíl však tkví již v samotné ústavní úpravě. Zatímco ústavní systém první Československé republiky byl postaven na tzv. zásadě negativního parlamentarismu, dnes je ústavní pořádek postaven na tzv. pozitivním parlamentarismu, který neumožňuje „nepolitickou“ vládu. To má své důsledky i pro vztah vlády ČR, Parlamentu a prezidenta republiky.

De constitutione ferenda je dokonce otázkou, zda by nebylo vhodnější pozitivní parlamentarismus dotáhnout do důsledků a vrátit se vlastně do roku 1918 - vládu volit. Mohlo by to odstranit některé nejasnosti a zpřehlednit ústavní vztahy, nicméně samozřejmě by to byl poměrně radikální zásah, který může mít nepředvídané důsledky a záleželo by tedy na konkrétní promyšlené úpravě.

\section{Pojem parlamentarismu}

Parlamentarismus jako takový je bud’ chápán jako jakákoliv forma vlády, v níž existuje parlament, nebo přesněji jako forma vlády se zvláštním postavením parlamentu ve státě.

1 Zákon č. 121/1920 Sb.

2 Celá pasáž zněla: „Prosím, abyste všichni měli vysoký úkol ten před očima a abyste dali se cele proniknouti velikostí jeho. Aby odlesk velikého toho díla padl i na debatu, a jmenovitě, aby na ní neulpělo nic z prachu rozvířeného blízkostí voleb, jak jsme to měli příležitost pozorovati při některých nedávných debatách. Každý z nás necht’ je si plně vědom toho, že slova jeho budou poslouchána tisíci, statisíci, snad miliony našich současníků a že mluví také k těm, kdož přijdou po nás, k budoucím generacím, jež se budou znovu a znovu vraceti k základům ústavy, jejíž vypracování je svěřeno ted' našim rukám a jejímuž projednávání právě ted' přistupujeme." Citováno podle KUKLÍK, J. Příběh československé ústavy 1920 I. Praha: Karolinum, 2020, s. 199.

3 Zejména zákon č. 1/1993 Sb.

4 Jak uvádí Tomáš Němeček, možnosti tvorby nové ústavy shrnul již na počátku činnosti vládní komise její tajemník Cyril Svoboda: bylo možné vycházet z československé ústavy z roku 1920, přepracovat dosavadní Ústavu ČSFR, anebo vypracovat zcela nový dokument. Nejen Svoboda, ale i ostatní členové komise směřovali k možnosti využití prvorepublikové ústavy. Viz NĚMEČEK, T. Vojtěch Cepl: Život právnika ve 20. století. Praha: Leges, 2010, s. 165.

5 Např. viz MARÈS, A. Edvard Beneš od slávy k propasti: drama mezi Hitlerem a Stalinem. Praha: Argo, 2016. 
Klasická učebnice státovědy uvádí, že jde o ten typ uspořádání vztahů nejvyšších státních orgánů charakterizovaný v zásadě tím, že parlament má výsadní postavení vůči ostatním nejvyšším orgánům. ${ }^{6}$ Hans Kelsen charakterizuje parlamentarismus obecně jako kompromis mezi demokratickým požadavkem svobody a zásadou diferencující dělby práce jakožto zásady, která podmiňuje všechen sociálně technický pokrok. ${ }^{7}$

Parlamentní režimy jsou nejstarší a v demokratických systémech i stále nejčastější formou vlády. Lze je sice poměrně jasně členit, ale pokud budeme uvažovat do důsledku, tak jsou podobně jako poloprezidentské či prezidentské režimy velmi různorodé a prakticky nenalezneme dva totožné př́íklady parlamentních režimů, a to ani např́ič historií. ${ }^{8}$ Miloš Brunclík v této souvislosti klade na první místo samožrejmě známé členění Giovanniho Sartoriho podle reálné politické moci vlády či přesněji jejího předsedy, ${ }^{9}$ nicméně členění může pokračovat podle pravidel pro rozpuštění komor, ${ }^{10}$ míry vládní kontroly nad legislativní agendou, strukturou parlamentních rozhodovacích mechanismů atd. ${ }^{11}$ Dále rozlišujeme parlamentarismus s převahou zákonodárného sboru a např. stranicky kontrolovaný parlamentarismus. ${ }^{12}$ Můžeme pak shodně s Vladimírem Klokočkou dále rozlišit režimy s parlamenty ,proslovư“, kde zákonodárný sbor slouží spíše jako tribuna k veřejnosti a parlamenty „pracovní“, reálně vykonávající státní moc. ${ }^{13}$

Jak s odkazem na Bohumila Baxu připomíná Jan Grinc, současná podoba a způsob fungování parlamentů jsou výrazně ovlivněny tím, jak se vyvinul parlament a parlamentní forma vlády v Anglii. ${ }^{14}$ Původně stavovské shromáždění povolovalo berně a podávalo králi petice na vydání zákona. Rozpočtová pravomoc se stala pákou pro rozvoj pravomocí dalších. ${ }^{15}$ Pro tuto práci je však základní vývoj vztahu parlamentu a moci výkonné.

$\mathrm{Z}$ logiky věci (a znovu jsme si to mohli uvědomit $\mathrm{v}$ případě řešení mimořádné situace pandemie COVID-19) má přirozeně navrch výkonná moc. Přesto lze dovodit, že se postupně moc parlamentu moci krále (výkonné moci) vyrovnává, až dochází k získání převahy. ${ }^{16}$ Ve skutečnosti je to však do jisté míry ,souboj“ dvou vrcholů výkonné moci - vlády a krále -, nebot' parlament v sobě vládu implicitně zahrnuje.

Zde je tedy podstatné zmínit, že k prvnímu návrhu na vyslovení nedůvěry vládě došlo v anglické ústavní historii až v březnu 1782, když po zprávách o britské porážce

$6 \quad$ PAVLÍČEK, V. a kol. Ústavní právo a státověda. 1. díl. Obecná státovéda. Praha: Linde, 1998, s. 231.

7 KELSEN, H. Problém parlamentarismu. Revue Parlament, 1926, č. V, s. 10-11.

8 BRUNCLÍK, M. Negativní parlamentarismus: cesta k efektivnějšímu fungování parlamentního režimu? Acta Politologica, 2009, Vol. 1, No. 2, s. 118.

9 SARTORI, G. Srovnávaci ústavní inženýrství. Zkoumáni struktur, podnětů a výsledků. Praha: Slon, 2001, s. 111, dle BRUNCLÍK, op. cit., s. 118.

10 Viz k tomu zajímavá nová studie BECHER, M. Dissolution power, confidence votes, and policymaking in parliamentary democracies. Journal of Theoretical Politics, 2019, 31, 2, 183-208.

11 Alan Siaroff v této souvislosti definoval dokonce 27 různých parlamentních režimů. Viz SIAROFF, A. Varieties of Parliamentarianism in the Advanced Industrial Democracies. International Political Science Review, 2003, Vol. 24, No. 4, dle BRUNCLÍK, op. cit., s. 119.

12 CABADA, L. - KUBÁT, M. a kol. Úvod do studia politické védy. Praha: Eurolex Bohemia, 2004, s. 202.

13 KLOKOČKA, V. Ústavni systémy evropských státù. Praha: Linde, 2006, s. 202.

14 Podrobně např. BAXA, B. Parlament a parlamentarism. Díl I. Parlament; jeho vývoj, složení a funkce. Praha: Jan Košatka, 1924. Citováno podle RESCHOVÁ, J. - KINDLOVÁ, M. - GRINC, J. - PREUSS, O. ANTOŠ, M. Státověda: stát, jednotlivec, konstitucionalismus. Praha: Wolters Kluwer, 2019.

15 Viz RESCHOVÁ - KINDLOVÁ - GRINC - PREUSS - ANTOŠ, op. cit.

16 Viz k tomu SVATOŇ, J. Vládní orgán moderního státu. Brno: Doplněk, 1997, s. 18. 
v Yorktownu v americké revoluční válce britský parlament odhlasoval, že ,již nemohou znovu získat důvěru přítomní ministřii“. Předseda vlády Lord North odpověděl žádostí, aby král Jiří III. přijal jeho demisi. Tak se podle Miloše Brunclíka postupně vytvořila odpovědnost vlády parlamentní většině. To v praxi znamená, že parlament může vládu odvolat (resp. vyslovit vládě nedůvěru), což je nejdůležitějším znakem parlamentních režimů. ${ }^{17}$ Naopak prezident je z výkonu své funkce neodpovědný, což celý vztah podstatně dokresluje.

\section{Pozitivní a negativní parlamentarismus}

Tato práce se ohlíží za posledními více než sto lety české a československé ústavní tradice. Tedy paměti, ze které můžeme čerpat a která nám v ústavním právu může být nápomocna v řešení dilemat dneška, zejména s přihlédnutím k Ústavní listině 1920.

Podstatnou tezí však je, že tato pomoc může být nepřímá, může také tkvět v poznání, že tradice vycházela z jiného základu, z jiných předpokladů a okolností, a rozhodnutí a závěry minulosti tak nelze na dnešní praxi bez dalšího aplikovat. Zde se právě dostáváme k meritu věci, k potřebě odlišit pojmy pozitivní a negativní parlamentarismus.

Dle uznávaných definic pro tzv. pozitivní parlamentarismus platí, že nelze vládnout bez aktivní (pozitivní) důvěry parlamentu. Vláda tedy musí získat výslovnou podporu parlamentní většiny pro to, aby se mohla ujmout úřadu, nebo bezprostředně poté, co je jmenována. Jak uvádí Miloš Brunclík, probíhá zde tedy formální hlasování o důvěře pro novou vládu, kterým se ověřuje, zda vláda skutečně většinovou podporu má. Jinak řečeno, platí zde vlastně presumpce nedůvěry. Důkazní břemeno spočívá na vládě, která musí osvědčit, že je většinou podporována. ${ }^{18}$

Naproti tomu negativní parlamentarismus vychází z toho, že vláda vládne, dokud jí to parlament toleruje, dokud jí nevysloví nedůvěru. Důkazní břemeno je zde na parlamentu, který může v zásadě kdykoliv demonstrovat svou nedůvěru vládě, která pak musí odejít, resp. podat demisi.

Mezi těmito systémy je fundamentální rozdíl. Negativní parlamentarismus předpokládá parlament spíše jako arbitra, který může vystavit „červenou kartu“, pokud vláda špatně vykonává své pravomoci. Pozitivní parlamentarismus naopak předpokládá užší vztah a užší propojení politické většiny v zákonodárném sboru a vlády, kdy tato většina je spíše skupinou delegátů odpovědných za výkon vlády, kterou si určují poslanci de facto jako výbor ze svých řad.

Negativní parlamentarismus je samozřejmě historicky starší varianta, nebot' je prvním stádiem přechodu od absolutistické vlády panovníka k parlamentní monarchii. ${ }^{19}$ Panovník přirozeně vládne a jmenuje si své ministry samostatně, postupně však parlament získává možnost tyto ministry přinutit $\mathrm{k}$ demisi (vyslovit jim nedůvěru), jak jsme zmiňovali

17 BRUNCLÍK, op. cit., s. 121.

18 Tamtéž. Brunclík zde dále uvádí, že pozitivní parlamentarismus může mít dvě základní podoby podle charakteru většiny, která je potřebná pro vyslovení důvěry. V některých režimech tohoto typu postačí, aby vláda získala prostou většinu v parlamentu. Takovým př́kladem je Bulharsko, Česká republika, Estonsko, Finsko (od r. 2000), Irsko, Itálie, Izrael, Lotyšsko, Lucembursko, Polsko či Slovensko. V jiných režimech musí získat vláda absolutní většinu poslaneckých křesel. Tak je tomu například v Mad’arsku, Německu, Rumunsku, Slovinsku, Belgii či Španělsku.

19 SVATOŇ, op. cit., s. 29. 
v př́ipadě britských vojenských neúspěchů v americké válce za nezávislost. Tato logika se nicméně postupně prosazuje a formalizuje až v 19. století.

\section{Problém tradice československé republiky}

Ústavní listina 1920 ve svém $§ 75$ stanovila, že vláda je odpovědna poslanecké sněmovně, která jí může vyslovit nedůvěru. K usnesení bylo třeba přítomnosti nadpoloviční většiny poslanců, nadpoloviční většiny hlasů a hlasování podle jmen. Následující § 76 pak doplňoval, že návrh na vyslovení nedůvěry musel být podepsán nejméně sto poslanci a přikázal se výboru, který o něm podal zprávu nejdéle do osmi dnů. § 77 pak dával toliko fakultativní možnost vlády předstoupit před sněmovnu s žádostí o důvěru, když uváděl, že vláda může podat v poslanecké sněmovně návrh na vyslovení důvěry. O takovém návrhu se jednalo, aniž byl přikázán výboru.

Lze tedy jasně dovodit, že se důvěra vlády předpokládá a testuje se jen v prrípadech politického rozhodnutí vlády nebo většiny ve sněmovně.

Naproti tomu naše současná Ústava v odst. 3 čl. 68 stanoví, že vláda předstoupí do třiceti dnů po svém jmenování před poslaneckou sněmovnu a požádá ji o vyslovení důvěry. Sněmovna má sice podle čl. 72 také možnost aktivně vládě vyslovit nedůvěru a vláda má podle čl. 71 možnost kdykoliv znovu o potvrzení důvěry žádat, klíčové je však právě ustanovení odst. 3 čl. 68. Toto pravidlo povinné žádosti o důvěru nově nastupující vlády posouvá celý mechanismus do úplně jiné roviny a maže se tím tradiční stopa negativního parlamentarismu.

Vychází se totiž z úplně jiného legitimizačního konceptu. Vláda musí mít zásadně vždy legitimitu opřenou o důvěru Poslanecké sněmovny, jinak nemůže plnohodnotně pokračovat, musí podat demisi. I Ústavní soud ČR k tomu podotýká, že postavení samotné prozatímní vlády (tedy vlády v demisi) je nutně ústavně omezujícím faktorem, který se musí projevit restriktivním přístupem $\mathrm{k}$ výkonu jak pravomoci vydávat nařízení dle čl. 78 Ústavy, tak při dalších aktech vládnutí, zejména pokud by nesly zásadní a nevratné důsledky. ${ }^{20}$

Vláda bez důvěry sněmovny tedy nemůže plnohodnotně vládnout. Tento systém nicméně počítá s určitou dobrou vírou vykonavatelů veřejných funkcí, kdy se spoléhá na to, že vláda, než důvěru po svém nástupu získá, jednak nebude vykonávat ony akty vládnutí, které by nesly zásadní a nevratné důsledky, ale samozřejmě, že je nebude vykonávat zejména, pokud o důvěru přijde, nebo ji dokonce nikdy nezíská.

Zde je pak na místě moderátorská role prezidenta republiky, který by měl velmi rychle jmenovat vládu novou. „Rychlost“ je zde samozřejmě pojem relativní a nelze patrně předem efektivně stanovit lhůtu. Přesto či spíše právě proto by prezident měl jednat bez zbytečného odkladu spíše v řádu dní či maximálně týdnů, než měsícủ či dokonce let (sic!). ${ }^{21}$ Tento korektní výkon pravomocí by samozřejmě mohla Ústava př́mo vynutit, pokud by

20 Jde o nález ve věci Pl. ÚS 6/07 ze dne 9. 2. 2010, 66/2010 Sb., bod 52.

21 Např. tzv. první vláda Andreje Babiše vládla od 13. prosince 2017 do 27. června 2018, přičemž dne 16. ledna 2018 nedostala důvěru Poslanecké sněmovny a následujícího dne sice podala demisi, kterou prezident Miloš Zeman přijal dne 24. ledna 2018, ale novou vládu jmenoval až po pěti měsících! Objevují se však i názory, že záleží čistě na prezidentovi, kdy ke jmenování nové vlády po neobdržení důvěry přistoupí. Viz např. KOUDELKA, Z. Prezident republiky. 2. aktualizované a doplněné vydání. Praha: Leges, 2018, s. 170. 
byla zvolena úprava, která vlastně vůbec neumožňuje, aby vznikla a ujmula se funkce vláda bez důvěry sněmovny.

Vrat'me se v této souvislosti ještě k tzv. Prozatímní ústavě. ${ }^{22}$ Ta při svém schválení počítala př́imo s volbou vlády shromážděním. Ve svém $§ 14$ nadepsaném O moci výkonné

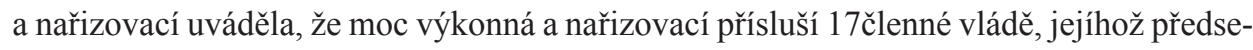
du a členy (ministry) volí Národní shromáždění. V § 78 pak umožňovala i odvolání takové vlády, když uváděla v odst. 1 tohoto paragrafu, že vyslovila-li poslanecká sněmovna vládě nedůvěru anebo zamítla-li vládní návrh na vyslovení důvěry, musí vláda podat demisi do rukou prezidenta republiky, který určuje, kdo vede vládní věci, pokud nová vláda nebude ustavena.

Nesmíme však přehlédnout, že tento model byl opuštěn již v roce 1919 pod tlakem prezidenta Masaryka a jeho slavné věty „Tož to ne!“‘, kdy důvodová zpráva k vládnímu návrhu novely Prozatímní ústavy (tisk č. 810) uvádí: „Vláda má za to, že by president republiky měl povolán býti $\mathrm{k}$ tomu, aby jmenoval členy vlády ... Vládní návrh vychází z názoru, že $\mathrm{z}$ důvodů ryze věcných president naší republiky by měl býti vypraven nositelstvím moci výkonné a vládní asi po vzoru francouzském a že by z toho důvodu měl býti pověřen podstatným důsledkem tohoto nositelství, t.j. pravomocí jmenovati členy vlády, kteří by za své zodpovědnosti vedli vládní záležitosti ... Svěřiti sněmovnám jmenování ministrů znamenalo by učiniti z ministrů pouhé zmocněnce parlamentu, t.j. zavésti všemohoucnost tohoto. Výběr ministerského předsedy, třebaže jest obmezen na majoritu sněmovní, je důležitou prerogativou hlavy státu, prerogativou, která tvoří protiváhu moci parlamentní. Je tedy srovnatelné s podstatou republiky, když se navrhuje, aby president republiky jmenoval ministry..." 23

Je sice pravda, že Antonín Švehla nebyl pro silného prezidenta, o této funkci hovořil jako o „monstranci nesené před procesím““.24 Praxe se však pod vlivem silné Masarykovy osobnosti ubírala trochu jiným směrem, kdy žádný premiér nenavrhl kandidáta, o kterém věděl, že s ním prezident nebude souhlasit. ${ }^{25}$ Masaryk žádal, aby ministrem zahraničí byl vždy Edvard Beneš. ${ }^{26}$ Premiéři se prezidentovi podř́ídili. Komické to bylo podle Antoina Marése v letech 1926-29, kdy Beneš byl ministr a jeho národně socialistická strana byla v opozici. Když byl v roce 1925 jmenován velvyslancem ve Velké Británii Jan Masaryk, bylo to kritizováno jako nepotismus. ${ }^{27}$ Vytvořila se tak nicméně tradice silného prezidenta, protiváhy proti parlamentu, která nikdy plně nedopovídala jeho ústavnímu postavení. Určitým paradoxem je, že tento stav a symbolika funkce prezidenta přetrvala i po převratu v únoru 1948, i když se často objevovala kritika spojování funkce prezidenta republiky a generálního tajemníka ÚV KSČ, silné osobnosti se opět o kumulaci zasadily. Např. Gustav Husák hovořil o zákazu kumulace jako o „takovém fetišizovaném pojmu“

\footnotetext{
22 Zákon č. 37/1918 Sb.

23 Důvodová zpráva k vládnímu návrhu novely Prozatímní ústavy (tisk č. 810).

24 MARÈS, op. cit., s. 172.

25 I na základě tohoto případu KOUDELKA, Z. Prezident nemusí jmenovat ministra. [online]. Česká justice, 16. 08. 2019. Dostupné na: https://www.ceska-justice.cz/blog/prezident-nemusi-jmenovat-ministra/. [cit. 21. 08. 2020].

26 MARÈS, op. cit., s. 136.

27 Tamtéž, s. 127.
} 
a i přes odpor části vedení a velké části nižších funkcionářů KSČ se v roce 1975 nechal prezidentem zvolit. ${ }^{28}$

Nimbus prezidenta pak přetrvává do jisté míry i v polistopadovém zřízení. Zde je však potřeba si připomenout, že nemůžeme vycházet z tradice Ústavní listiny 1920, ani pokud jde o vztah hlavy státu a předsedy vlády. Jak uvádí Jan Kysela a Jan Wintr, ze známé typologie postavení předsedů vlád podle G. Sartoriho (první nad nerovnými, první mezi nerovnými a první mezi rovnými) je český premiér ve své vládě ústavně prvním mezi nerovnými, a to na rozdíl od meziválečného Československa, pro něž byla referenční francouzská Třetí republika, v níž byl předseda vlády prvním mezi rovnými. Vláda tak sice je kolegiátní orgán, rozhoduje ve sboru nadpoloviční většinou všech členů vlády (čl. 76 Ústavy), přičemž předseda má jeden hlas jako každý jiný člen vlády. Premiér však určuje složení své vlády - vybírá si všechny ostatní členy vlády (prezident je jmenuje na jeho návrh), může kteréhokoli vicepremiéra či ministra z vlády odstranit (prezident je totiž povinen vyhovět premiérovi, který navrhne odvolání člena vlády, srov. níže), a Poslanecká sněmovna nemůže vyslovením nedůvěry donutit jednotlivého člena vlády k demisi; za trvání vlády je tedy člen vlády ústavně závislý jedině na důvěře premiéra. ${ }^{29}$

Nelze tedy i přes výše uvedená vzletná zdůvodnění přeceňovat vliv prezidenta republiky na vládu a její složení. Zejména pokud jde o odvolání ministra. Samozrejmě pak platí i to, že vláda trvá v osobě svého předsedy. ${ }^{30}$

Přes poměrně jasné výkladové závěry by stálo za úvahu, tak, jak bylo naznačeno v úvodu, celou věc ještě více vyjasnit a posílit jasnost vztahu mezi vládou a Poslaneckou sněmovnou. Ideálním nástrojem se jeví volba předsedy vlády, tedy určitý kancléřský systém, doplněný o možnost vlády vhodně sněmovnu rozpustit, či to významně ovlivnit. Nicméně takový zásah by vyžadoval hlubší promyšlení a velmi pečlivé nastavení, aby paradoxně systém nenarušil, a ještě sílu vlády neumenšil (prezident by ji nemohl „,chránit“ ve své roli ,protiváhy“'). Michael Becher napřr. dovozuje, že za určitých okolností může dokonce formální posílení předsedy vlády vést $\mathrm{k}$ jeho faktickému oslabení. ${ }^{31}$

\section{Závěr}

Je zřejmé, že tradice první republiky a zvláště Ústavní listiny 1920 je stále velmi důležitá a živá v interpretaci našeho současného ústavního systému. V mnohém jsme navázali a mnohé jsme se snažili vylepšit.

V oblasti parlamentarismu a vztahu vlády a prezidenta republiky jsme se však rozhodli jít jinou cestou, byt' to na první pohled nemusí být zřejmé. Zatímco ústavní systém první Československé republiky byl postaven na tzv. zásadě negativního parlamentarismu, kdy vláda nastupuje z vůle prezidenta a Parlament ji má možnost přimět k odchodu vyslovením nedůvěry, dnes je ústavní pořádek postaven na tzv. pozitivním parlamentarismu, který je založen na pozitivní politické důvěře a neumožňuje tak „nepolitickou“ vládu. Prezidenti sice stále navazují na silnou interpretační pozici svého úřadu, pohybují se však v jiných mantinelech. Z toho však vznikají do jisté míry zbytečné třenice a nejasnosti.

\footnotetext{
28 MACHÁC̆EK, M. Gustáv Husák. Praha: Vyšehrad, 2017, s. 447.

29 KYSELA, J. - WINTR, J. Ústavní rozměr vládní krize z května 2017. Právní rozhledy, 2017, č. 13-14, s. 6.

$30 \quad$ Viz k tomu tamtéž.

31 BECHER, op. cit.
} 
De constitutione ferenda je tedy legitimní otázkou, kterou jsme tu položili, zda by nebylo vhodnější pozitivní parlamentarismus dotáhnout do důsledků a vrátit se vlastně do roku 1918 - vládu volit. Mohlo by to (jednou pro, nikoliv vždy, ale dlouhý čas) odstranit některé nejasnosti a zpřehlednit ústavní vztahy, nicméně samozřjejmě by to byl poměrně radikální zásah, který může mít nepředvídané důsledky.

Čistý parlamentarismus je samozrejmě pro společnost též nebezpečným systémem, který může ohrozit fungování státu. Protiváha prezidenta musí být nahrazena silnějším předsedou vlády. Krajně rozdrobený sněm nepřináší žádná výrazná pozitiva, ač zde mohou zaznívat různorodé názory, nelze často dojít k žádnému konsenzu a vláda tak vlastně vůbec dlouhodobě vládnout nemůže. Jednoduše může parlament sklouznout do anekdoty, kterou vzpomíná Jan Wintr a která Parlament definuje jako něco mezi muzeem a divadlem. ${ }^{32}$ Vláda bez legitimity je však ještě nebezpečnější a nelze souhlasit s tím, že je vhodné nechat takovou vládu rozhodovat klíčové otázky fungování státu po dlouhé měsíce či dokonce roky.

32 WINTR, J. Česká parlamentní kultura. Praha: Auditorium, 2010, s. 5. 